\title{
$\mathrm{Pr}-\mathrm{Fe}-\mathrm{Co}-\mathrm{W}-\mathrm{B}$ 系交換スプリング磁石の磁気特性
}

\author{
正 員 山元 洋* 学生員 齋木 正親**
}

\section{Magnetic Properties of Pr-Fe-Co-W-B System Exchange Spring Magnets}

Hiroshi Yamamoto*, Member, Masachika Saiki**, Student Member

The melt-spun ribbons of Pr-Fe-Co-W-B system alloys were prepared by single roller rapid-quenching method. The effects of composition, wheel velocity and heat-treatment on the magnetic properties were investigated. The $\mathrm{Pr}_{9} \mathrm{Fe}_{76.7} \mathrm{Co}_{8} \mathrm{~W}_{0.3} \mathrm{~B}_{6}$ ribbon prepared at a wheel velocity of $15.0 \mathrm{~m} / \mathrm{s}$ were crystallized by heat-treatment, and the optimum heat-treatment condition was found to be at $600{ }^{\circ} \mathrm{C}$ for $3 \mathrm{~min}$, then the value of $(B H)_{\max }$ was 148.5 $\mathrm{kJ} / \mathrm{m}^{3}$. The temperature coefficients of $J_{r}$ and $H_{c J}$ for the ribbons crystallized from the amorphous $\mathrm{Pr}_{9} \mathrm{Fe}_{76.7} \mathrm{Co}_{8} \mathrm{~W}_{0.3} \mathrm{~B}_{6}$ alloy were $\alpha\left(J_{r}\right)=-0.03 \% /{ }^{\circ} \mathrm{C}$ (reversible)and $\alpha\left(H_{c J}\right)=-0.45 \% /{ }^{\circ} \mathrm{C}$ (irreversible), respectively. The value of $(\mathrm{BH})_{\max }$ for the compression molding $\mathrm{Pr}_{9} \mathrm{Fe}_{76.7} \mathrm{Co}_{8} \mathrm{~W}_{0.3} \mathrm{~B}_{6}$ isotropic bonded magnet prepared by using the ribbons annealed at $600{ }^{\circ} \mathrm{C}$ for $3 \mathrm{~min}$ is $86.00 \mathrm{~kJ} / \mathrm{m}^{3}$ and the density is $6.16 \mathrm{Mg} / \mathrm{m}^{3}$.

キーワード : Pr-Fe-Co-W-B 系合金, 急冷薄帯, 交換スプリング磁石, 磁気特性, ボンド磁石

Keywords : Pr-Fe-Co-W-B system alloys, melt-spun ribbons, exchange spring magnet, magnetic properties, bonded magnet

\section{1. 緒 言}

硬質磁性材料中に鉄のような軟質磁性材料をいれたナノ コンポジットを構成すると，両者の間に交換結合がある場 合には単一の硬質磁性材料のように振る舞う。このような 交換結合磁石は, 減磁曲線で磁化が外部磁界に対して可逆 的にスプリングバックする特異な挙動を示すことから交換 スプリング磁石と呼ばれている。

これら交換スプリング磁石における, $\mathrm{Nd}-\mathrm{Fe}-\mathrm{Co}-\mathrm{B}$ 合金に 添加物を加えることにより，1.0 T 以上の高い残留磁束密度 が得られるという報告がある(1) (4)。また, Nd を Pr で置換 すると， $\mathrm{Pr}_{2} \mathrm{Fe}_{14} \mathrm{~B}$ 型結晶相の異方性磁界が高いために，保 磁力が大きくなることが予想される。そして, 著者らの一 人は以前に $\mathrm{Sm}-\mathrm{Fe}$ 系の窒化化合物作製時に, Sm-Fe 合金に $\mathrm{W}$ を添加すると微細組織になることを報告している(5)。

そこで本実験では Pr-Fe-Co-W-B 系急冷薄帯において, 高性能な $\alpha-\mathrm{Fe} / \mathrm{Pr}_{2} \mathrm{Fe}_{14} \mathrm{~B}$ 系交換スプリング磁石を作製する ことを目的に, $\operatorname{Pr}$ 量, $\mathrm{B}$ 量を変化させ, さらに $\mathrm{Fe}$ の一部 を $\mathrm{W}$ で置換し, ロール周速度 (急冷速度), 熱処理などの 諸条件が薄帯磁石の磁気的, 物理的特性にどのような影響

\footnotetext{
* 明治大学

干214-8571 川崎市多摩区東三田 1-1-1

Meiji University

1-1-1, Higashimita, Tama-ku, Kawasaki 214-8571

** 明治大学 大学院

干214-8571 川崎市多摩区東三田 1-1-1

Graduate School, Meiji University

1-1-1 Higashimita, Tama-ku, Kawasaki 214-8571
}

を与えるかについて，詳細に実験検討した。また，これら 薄帯試料の粉末を用いてボンド磁石を作製し, それらの諸 特性についても詳細に検討をした。

\section{2. 実験方法}

実験に用いた原材料は, $\mathrm{Pr}, \mathrm{Fe}, \mathrm{Co}$ の金属, $\mathrm{Fe}-\mathrm{W}$ 合金 (W:77.73 wt％）と，メタロイドのBである。急冷薄帯作 製に用いた試料は, 組成式を $\mathrm{Pr}_{y} \mathrm{Fe} 92-x y z \mathrm{Cos}_{x} \mathrm{~B}_{z}$ とし, $\mathrm{Pr}$ 量 $y=8 \sim 10$ at $\%$, W 量 $x=0 \sim 0.5$ at $\%, B$ 量 $z=5 \sim 10$ at $\%$ と変化させたものである。上記の母合金は, 真空吸い上げ 法により作製した。急冷薄帯は高純度 $\mathrm{Ar}$ ガス雾囲気中にお いてロール周速度を $12.5 \sim 17.5 \mathrm{~m} / \mathrm{s}$ と変化させて片ロール 液体急冷法により作製した。熱処理は高純度 $\mathrm{Ar}$ ガス雾囲気 中で温度を 550 650 ${ }^{\circ} \mathrm{C}$ ， キープ時間を $3 \mathrm{~min}$ 一定として， 昇温時間を $1 \sim 10 \mathrm{~min}$ と変化させて行った。急冷薄帯の組 織は, TEM により観察した。薄帯試料の磁気特性, 温度特 性は全て $4.8 \mathrm{MA} / \mathrm{m}$ のパルス着磁を行った後に, VSM（振 動試料型磁力計）を用いて測定した。薄帯の結晶構造は粉 末 X 線回折法により調べた。またほぼ非晶質試料の結晶化 温度は, DTA（示差熱分析計）を用いて測定した。次にこ れらの薄帯試料を $150 \mu \mathrm{m}$ 以下に粉砕して, エポキシ樹脂 $2.5 \mathrm{wt} \%$ を混合擋拌し, $980 \mathrm{MPa}$ の圧力で圧縮成形した後, $150{ }^{\circ} \mathrm{C} \times 1 \mathrm{~h}$ のキュア処理を行いボンド磁石を作製した。ボ ンド磁石の磁気特性は, $4.8 \mathrm{MA} / \mathrm{m}$ のパルス着磁後, 高感度 自記磁束計を用いて測定した。 


\section{3. 実験結果並びに検討}

図 1 は ProFe76.7 $\mathrm{Co}_{8} \mathrm{~W}_{0.3} \mathrm{~B}_{6}$ 組成において, ロール周速度を $15.0 \mathrm{~m} / \mathrm{s}$ で作製した急冷薄帯試料のDTA曲線を示したもの である。なお DTA の昇温速度は $20^{\circ} \mathrm{C} / \mathrm{min}$ で行った。図よ り， $\alpha-\mathrm{Fe}$ 型結晶相への結晶化に対応した発熱ピークは $442{ }^{\circ} \mathrm{C}, \mathrm{Pr}_{2} \mathrm{Fe}_{14} \mathrm{~B}$ 型結晶相の結晶化開始温度は $490{ }^{\circ} \mathrm{C}$, 結

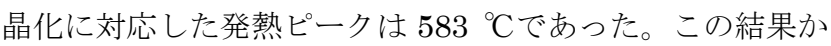
ら急冷薄帯の熱処理温度は $550{ }^{\circ} \mathrm{C}$ 以上で行った。

次に本研究の主目的である $\mathrm{W}$ 添加について検討した。図 2 は $\mathrm{Pr}_{9} \mathrm{Fe} 7{ }_{7-x} \mathrm{Co}_{8} \mathrm{~W}_{x} \mathrm{~B}_{6}$ 組成急冷薄帯試料において, W 量 $x$ $=0, \quad 0.1 ， 0.2 ， 0.3 ， 0.5$ at $\%$ と変化させたときの磁気特性 を示したものである。作製条件は，ロール周速度 $15.0 \mathrm{~m} / \mathrm{s}$, 熱処理条件 $600{ }^{\circ} \mathrm{C} \times 3 \mathrm{~min}$, 昇温時間 $5 \mathrm{~min}$ 一定とした。

(なおこの作製条件は，以下における $\mathrm{Pr}$ 量変化，B 量変化 の実験でも同様である。）図から知られるように，残留磁化 $J_{r}$ は $\mathrm{W}$ 量の増加とともに減少するという傾向にあり, 磁気

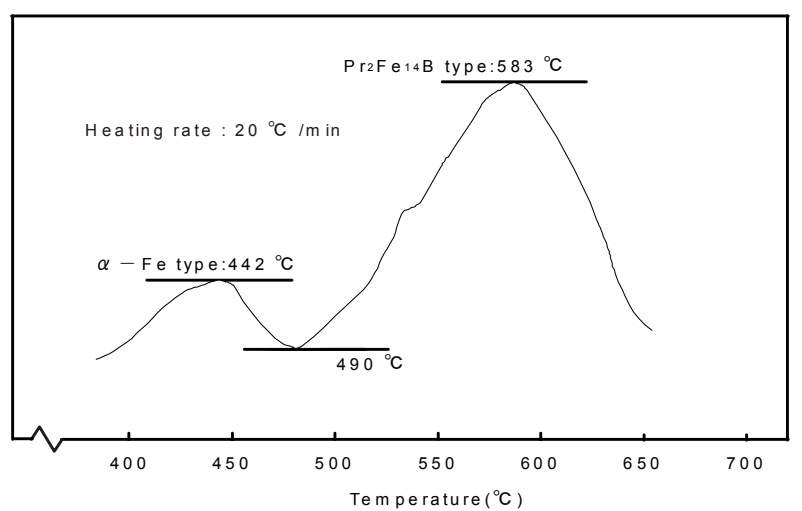

図 $1 \mathrm{Pr}_{9} \mathrm{Fe}_{76.7} \mathrm{Co}_{8} \mathrm{~W}_{0.3} \mathrm{~B}_{6}$ 合金急冷薄帯の DTA 曲線

Fig. 1. DTA curve for melt-spun $\mathrm{Pr}_{9} \mathrm{Fe}_{76.7} \mathrm{Co}_{8} \mathrm{~W}_{0.3} \mathrm{~B}_{6}$ alloy ribbon.

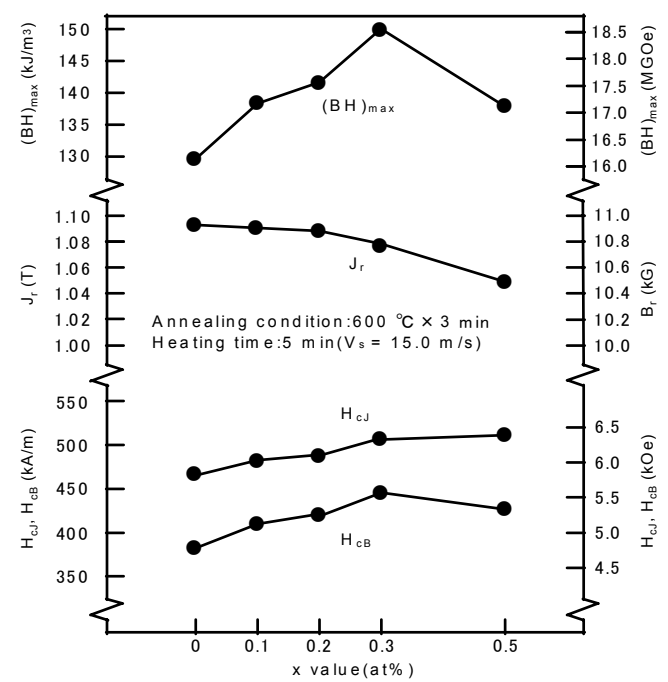

図 $2 \quad \operatorname{Pr}_{9} \mathrm{Fe}_{77-x} \mathrm{Co}_{8} \mathrm{~W}_{x} \mathrm{~B}_{6}$ 合金急冷薄帯の磁気特性

Fig. 2. Magnetic properties of melt-spun $\operatorname{Pr}_{9} \mathrm{Fe}_{77-\mathrm{x}} \mathrm{C}_{0} 8 \mathrm{~W}_{\mathrm{x}} \mathrm{B}_{6}$ alloy ribbons.
分極の保磁力（固有保磁力） $H_{c J}$ は $\mathrm{W}$ 量の増加とともに増 加し, 磁束密度の保磁力 $H_{c B}$, 最大エネルギー積 $(B H)_{\text {max }}$ は $x=0.3$ at $\%$ の時最大值をとり, 以後減少するという傾向に なった。これは, 0.5 at\%の組成では $H_{c B}$ が減少しているこ とから, 減磁曲線の角形比が低下したことが原因であると 考えられる。

次に各組成の結晶構造を調べるために，これら薄帯試料 の X 線回折を行った（図 3)。図から分かるように，どの組 成の急冷薄帯試料においても， $\alpha-\mathrm{Fe}$ 型結晶相と $\mathrm{Pr}_{2} \mathrm{Fe}_{14} \mathrm{~B}$ 型結晶相の回折線が明瞭に現れ, 複合組織であることが分 かった。

以上の磁気特性と $\mathrm{X}$ 線回折図形の解析の結果より, 最適 $\mathrm{W}$ 量 $x=0.3 \mathrm{at} \%$ として以後実験検討を行った。

図 4 は $\mathrm{Pr}_{\mathrm{y}} \mathrm{Fe} 85.7-\mathrm{y} \mathrm{Cos}_{0.3} \mathrm{~B}_{6}$ 組成急冷薄帯試料において, $\operatorname{Pr}$ 量 $y=8,9,10 \mathrm{at} \%$ と変化させたときの磁気特性を示し たものである。図から分かるように， $J_{r}$ は $\operatorname{Pr}$ 量の増加とも に減少し, $H_{c J}, H_{c B}$ は $\operatorname{Pr}$ 量の増加とともに増加する傾向に あり，(BH) max 減少した。この結果より, 最適 $\operatorname{Pr}$ 量 $y=9$ at\%として以後 実験検討を行った。

図 5 は $\mathrm{Pr}_{9} \mathrm{Fe}_{82.7-z} \mathrm{Co}_{8} \mathrm{~W}_{0.3} \mathrm{~B}_{z}$ 組成急冷薄帯試料において, $\mathrm{B}$ 量 $Z=5,6,8,10$ at\%と変化させたときの磁気特性を示 したものである。図から知られるように，J $J_{r}$ は B 量の増加 とともに減少し, $H_{c J}, H_{c B}$ は $z=6 \mathrm{at} \%$ のきに最大となり その後減少する傾向にあった。 $(B H)_{\max }$ は $z=6$ at\%のとき に最大值となった。この結果より, 最適 B 量 $z=6$ at $\%$ であ ることが分かった。

以上の結果より，最適組成は $\mathrm{Pr}_{9} \mathrm{Fe}_{76.7} \mathrm{Co}_{8} \mathrm{~W}_{0.3} \mathrm{~B}_{6}$ 組成で あることが分かったので，次にこの組成においてロール周

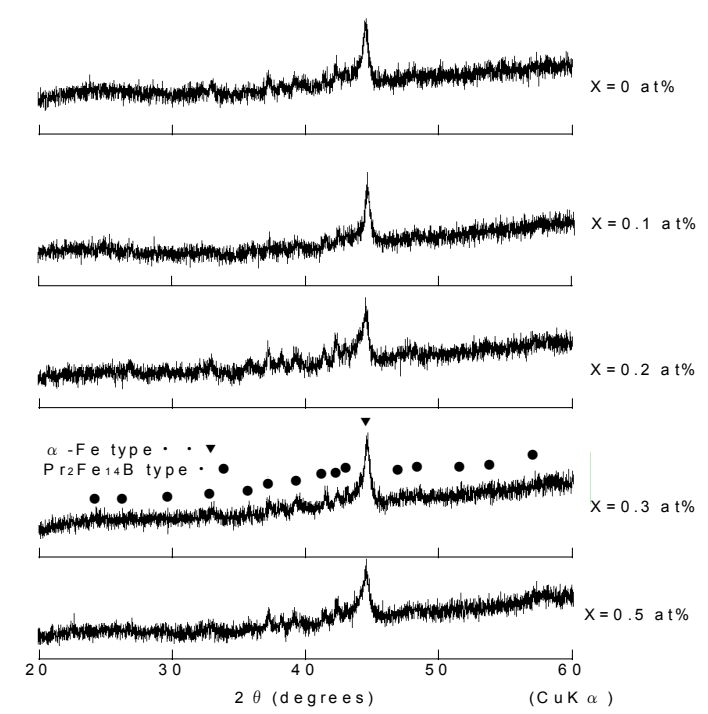

図 $3 \operatorname{Pr}_{9} \mathrm{Fe}_{77}{ }_{x} \mathrm{Co}_{8} \mathrm{~W}_{x} \mathrm{~B}_{6}$ 合金急冷薄帯の $\mathrm{X}$ 線回折図形 Fig. 3. X-ray diffraction patterns of melt-spun $\mathrm{Pr}_{9} \mathrm{Fe}_{77-} \mathrm{Co}_{8} \mathrm{~W}_{x} \mathrm{~B}_{6}$ alloy ribbons. 


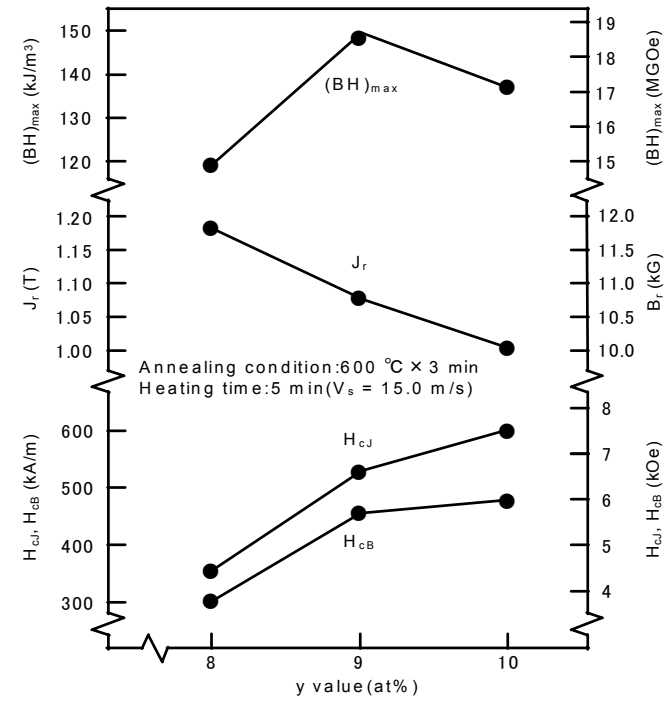

図 $4 \mathrm{Pr}_{\mathrm{y}} \mathrm{Fe}_{85.7-y} \mathrm{Co}_{8} \mathrm{~W}_{0.3} \mathrm{~B}_{6}$ 合金急冷薄帯の磁気特性

Fig. 4. Magnetic properties of melt-spun $\mathrm{Pr}_{\mathrm{y}} \mathrm{Fe} 85.7-{ }_{-y} \mathrm{Cos}_{8} \mathrm{~W}_{0.3} \mathrm{~B}_{6}$ alloy ribbons.

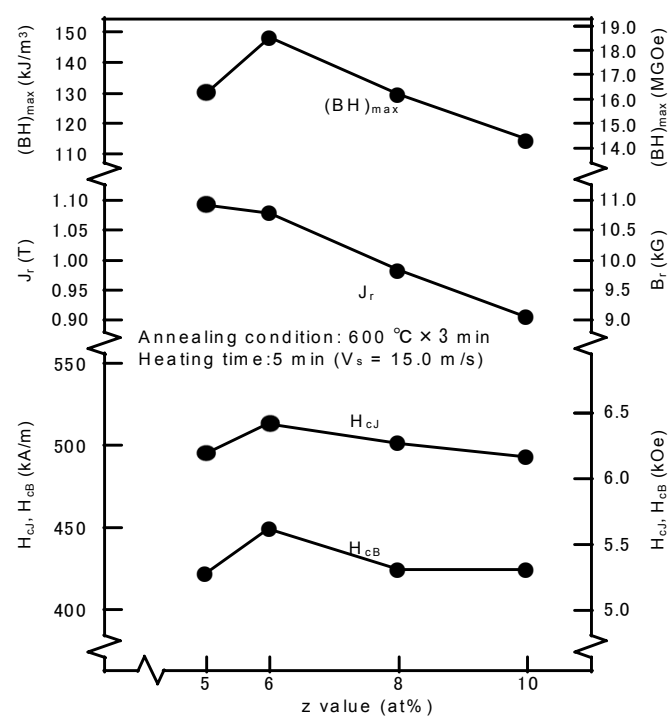

図 $5 \quad \mathrm{Pr}_{9} \mathrm{Fe}_{82.7-z} \mathrm{Co}_{8} \mathrm{~W}_{0.3} \mathrm{~B}_{z}$ 合金急冷薄帯の磁気特性

Fig. 5. Magnetic properties of melt-spun $\mathrm{Pr}_{9} \mathrm{Fe}_{82.7-z} \mathrm{Co}_{0} \mathrm{~W}_{0.3} \mathrm{~B}_{z}$ alloy ribbons.

速度を $12.5 \sim 17.5 \mathrm{~m} / \mathrm{s}$ と変化させ，磁気特性に及ぼす影響 について調べた (図 6)。なお熱処理条件は, $600{ }^{\circ} \mathrm{C} \times 3 \mathrm{~min}$, $600{ }^{\circ} \mathrm{C}$ までの昇温時間 $5 \mathrm{~min}$ 一定とした。この図から, $H_{c J}$, $H_{c B}, \quad J_{r}, \quad(B H)_{\max }$ のすべての值においてロール周速度 15.0 $\mathrm{m} / \mathrm{s}$ のときに最大值となった。この結果より, 最適ロール周 速度は $15.0 \mathrm{~m} / \mathrm{s}$ であることが知られた。

次に，熱処理条件を変化させて実験検討を行った。図 7 は $\mathrm{Pr}_{9} \mathrm{Fe}_{76.7} \mathrm{Co}_{8} \mathrm{~W}_{0.3} \mathrm{~B}_{6}$ 組成急冷薄帯試料において, 熱処理温 度を 550〜 $650{ }^{\circ} \mathrm{C}$ 変化させたときの磁気特性を示したも のである。なお作製条件は，ロール周速度 $15.0 \mathrm{~m} / \mathrm{s}$, 熱処 理時間 $3 \mathrm{~min}$, 昇温時閒 $5 \mathrm{~min}$ 一定とした。図から分かる ように, $H_{c J}$ は $625{ }^{\circ} \mathrm{C}$ で最大となりその後減少し, $H_{c B}, J_{r}$,

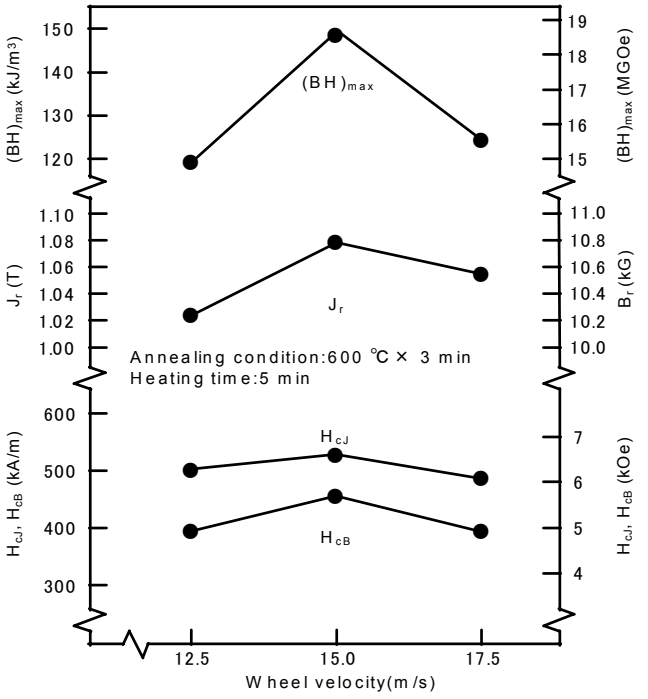

図 $6 \mathrm{Pr}_{9} \mathrm{Fe}_{76.7} \mathrm{Co}_{8} \mathrm{~W}_{0.3} \mathrm{~B}_{6}$ 合金急冷薄帯の磁気特性に 及ぼすロール周速度の影響

Fig. 6. Effect of wheel velocity on magnetic properties of melt-spun $\mathrm{Pr}_{9} \mathrm{Fe}_{76.7} \mathrm{Co}_{8} \mathrm{~W}_{0.3} \mathrm{~B}_{6}$ alloy ribbons.

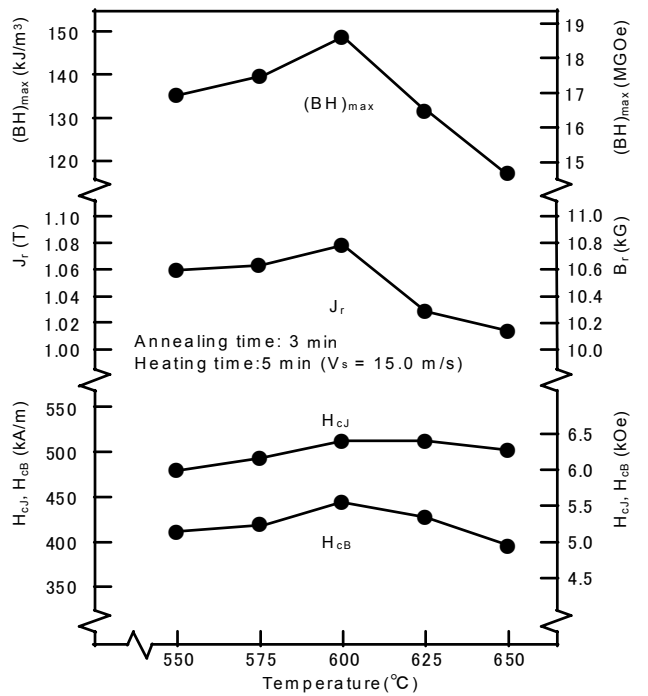

図 $7 \quad \operatorname{Pr}_{9} \mathrm{Fe}_{76.7} \mathrm{Co}_{8} \mathrm{~W}_{0.3} \mathrm{~B}_{6}$ 合金急冷薄帯の磁気特性に 及ぼす熱処理温度の影響

Fig. 7. Effect annealing temperature on magnetic properties of melt-spun $\mathrm{Pr}_{9} \mathrm{Fe}_{76.7} \mathrm{Co}_{8} \mathrm{~W}_{0.3} \mathrm{~B}_{6}$ alloy ribbons.

$(B H)_{\max }$ は $600{ }^{\circ} \mathrm{C}$ で最大となりその後減少した。図 8 はこ のときの X 線回折図形を示したものである。この図より， As-melt-spun では, $\alpha-\mathrm{Fe}$ 型の結晶がでているもののほぼ 非晶質となっている。また, 各熱処理温度において, $\alpha-\mathrm{Fe}$ 型結晶相と $\mathrm{Pr}_{2} \mathrm{Fe}_{14} \mathrm{~B}$ 型結晶相の回折線が明瞭に現れ, 複合 組織であることが分かった。

以上の磁気特性と X 線回折図形の解析の結果より，この

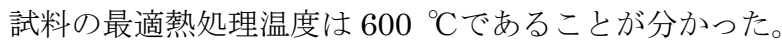

続いて，熱処理昇温時間を変化させて実験検討を行った。 


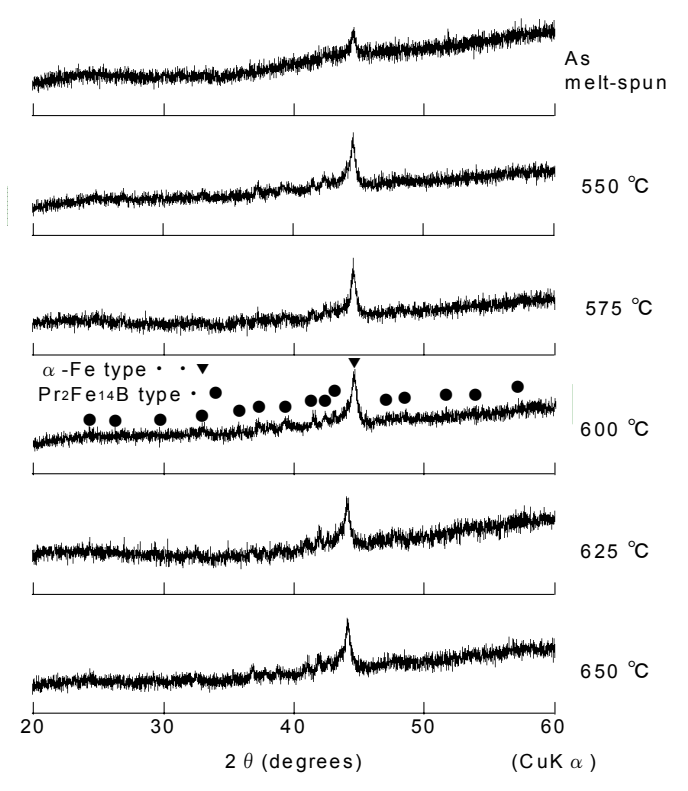

図 $8 \operatorname{Pr}_{9} \mathrm{Fe}_{76.7} \mathrm{Co}_{8} \mathrm{~W}_{0.3} \mathrm{~B}_{6}$ 合金急冷薄帯の 熱処理温度別 $\mathrm{X}$ 線回折図形

Fig. 8. X-ray diffraction patterns of melt-spun $\mathrm{Pr}_{9} \mathrm{Fe}_{76.7} \mathrm{Co}_{8} \mathrm{~W}_{0.3} \mathrm{~B}_{6}$ alloy ribbons as a function of annealing temperature.

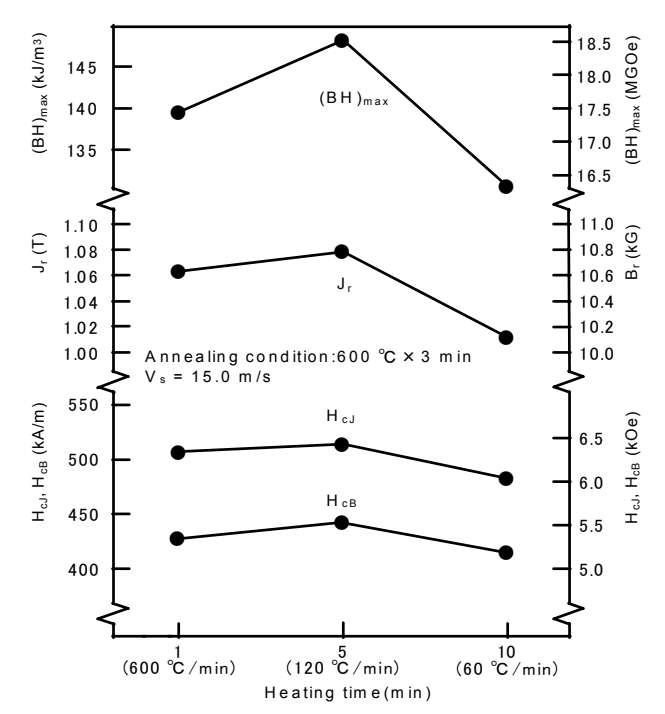

図 $9 \mathrm{Pr}_{9} \mathrm{Fe}_{76.7} \mathrm{Co}_{8} \mathrm{~W}_{0.3} \mathrm{~B}_{6}$ 合金急泠薄帯の 磁気特性に及ぼす熱処理昇温時間の影響

Fig. 9. Effect of heating time on magnetic properties of melt-spun $\mathrm{Pr}_{9} \mathrm{Fe}_{76.7} \mathrm{Co}_{8} \mathrm{~W}_{0.3} \mathrm{~B}_{6}$ alloy ribbons.

図 9 は $\mathrm{Pr}_{9} \mathrm{Fe}_{76.7} \mathrm{Co}_{8} \mathrm{~W}_{0.3} \mathrm{~B}_{6}$ 組成急冷薄帯試料において，熱 処理昇温時間を 1〜10 min と変化させたときの磁気特性を 示したものである。なお作製条件は, ロール周速度 15.0 $\mathrm{m} / \mathrm{s}$, 熱処理条件 $600{ }^{\circ} \mathrm{C} \times 3 \mathrm{~min}$ 一定とした。図から分かる ように, $H_{c J}, H_{c B}, J_{r},(B H)_{\max }$ すべての值において $5 \mathrm{~min}$ で最大值となった。以上の結果より, 最適熱処理条件は

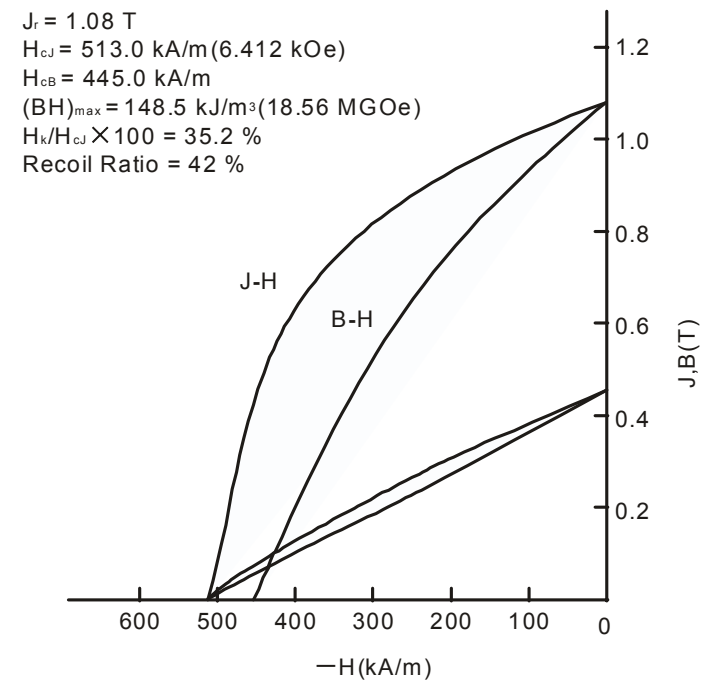

図 $10 \quad \operatorname{Pr}_{9} \mathrm{Fe}_{76.7} \mathrm{Co}_{8} \mathrm{~W}_{0.3} \mathrm{~B}_{6}$ 合金急冷薄帯の 減磁曲線およびリコイルループ

Fig. 10. Demagnetization curves and recoil loop of melt-spun $\mathrm{Pr}_{9} \mathrm{Fe}_{76.7} \mathrm{Co}_{8} \mathrm{~W}_{0.3} \mathrm{~B}_{6}$ alloy ribbon.

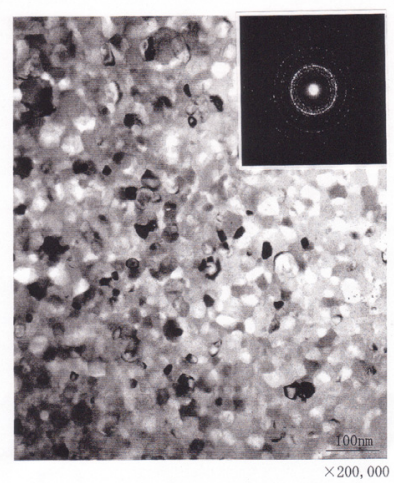

$\mathrm{Pr}_{9} \mathrm{Fe}_{77} \mathrm{Co}_{8} \mathrm{~B}_{6}$

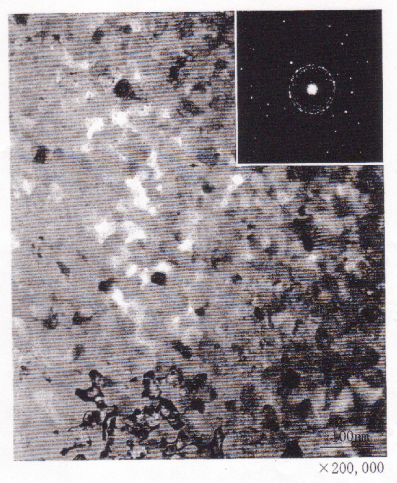

$\mathrm{Pr}_{9} \mathrm{Fe}_{76.7} \mathrm{Co}_{8} \mathrm{~W}_{0.3} \mathrm{~B}_{6}$
Annealing condition : $600{ }^{\circ} \mathrm{C} \times 3 \mathrm{~min}$ Heating time : $5 \mathrm{~min}\left(\mathrm{~V}_{\mathrm{s}}=15.0 \mathrm{~m} / \mathrm{s}\right)$

\section{図 11 急冷薄帯の TEM 写真}

Fig. 11. TEM photographs of melt-spun alloy ribbons.

$600{ }^{\circ} \mathrm{C} \times 3 \mathrm{~min}$, 熱処理昇温時間 $5 \mathrm{~min}$ ということが知ら れた。

図 10 は前述した最適作製条件で作製された $\mathrm{Pr}_{9} \mathrm{Fe}_{76.7} \mathrm{Co}_{8} \mathrm{~W}_{0.3} \mathrm{~B}_{6}$ 組成急冷薄帯試料の減磁曲線における スプリングバック及び磁気特性を示したものである。この 時の磁気特性は, $J_{r}=1.08 \mathrm{~T}, H_{c J}=513.0 \mathrm{kA} / \mathrm{m}, H_{c B}=445.0$ $\mathrm{kA} / \mathrm{m},(B H)_{\text {max }}=148.5 \mathrm{~kJ} / \mathrm{m}^{3}$, 角形比 $H_{k} / H_{c J} \times 100=$ $35.2 \%$ \%あった。またスプリングバック率として保磁力付 近から磁界を戻したときに残留磁化が約 $42 \%$ 回復すること が知られた。このことより, 本組成急冷薄帯試料は交換ス プリング磁石であることが確認された。

図 11 は, $\mathrm{Pr}_{9} \mathrm{Fe}_{77} \mathrm{Co}_{8} \mathrm{~B}_{6}$ 組成と $\mathrm{Pr}_{9} \mathrm{Fe}_{76.7} \mathrm{Co}_{8} \mathrm{~W}_{0.3} \mathrm{~B}_{6}$ 組成の 急冷後の試料に, 熱処理条件 $600{ }^{\circ} \mathrm{C} \times 3 \mathrm{~min}$, 熱処理昇温 


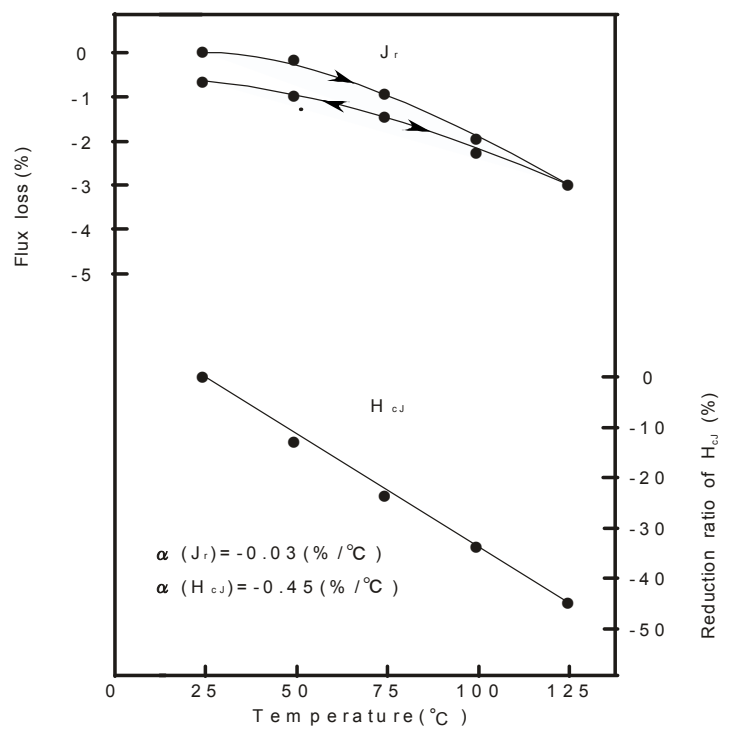

図 $12 \operatorname{Pr}_{9} \mathrm{Fe}_{76.7} \mathrm{Co}_{8} \mathrm{~W}_{0.3} \mathrm{~B}_{6}$ 合金急冷薄帯の

\section{$J_{r}, H_{c J}$ の温度特性}

Fig. 12. Temperature dependence of $J_{r}$ and $H_{c J}$ in melt-spun $\mathrm{Pr}_{9} \mathrm{Fe}_{76.7} \mathrm{Co}_{8} \mathrm{~W}_{0.3} \mathrm{~B}_{6}$ alloy ribbon.

時間 $5 \mathrm{~min}$ を施した後の TEM 写真である。この写真より， 両試料ともほとんどが結晶粒子で構成されており， $\mathrm{Pr}_{9} \mathrm{Fe}_{77} \mathrm{Co}_{8} \mathrm{~B}_{6}$ 組成の結晶の平均粒径は約 $30 \mathrm{~nm}$, $\mathrm{Pr}_{9} \mathrm{Fe}_{76.7} \mathrm{Co}_{8} \mathrm{~W}_{0.3} \mathrm{~B}_{6}$ 組成の結晶の平均粒径は約 $23 \mathrm{~nm}$ であ り，W 添加によって結晶が約 $7 \mathrm{~nm}$ 小さくなったことが分 かった。このことにより $\mathrm{W}$ 添加が若干ではあるが微細結晶 形成に寄与して，粒子間相互作用を強くしているために， 先に述べた磁気特性が向上しているものと考えられる。ま た，電子回折写真より両試料とも等方性であることが確認 された。

次に温度特性について実験検討を行った。図 12 は前述の 急冷薄帯試料の残留磁化 $J_{r}$ と保磁力 $H_{c J}$ において, 温度を 25〜 $125{ }^{\circ} \mathrm{C}$ まで変化させたときの温度特性を示したもので ある。図から分かるように, $J_{r}, H_{c J}$ は温度の上昇とともに 減少する傾向にあり， $J_{r}$ は温度を $125{ }^{\circ} \mathrm{C}$ から戻したとき， 温度に対して直線的には变化しなかった。 $J_{r}$ の温度係数は $\alpha\left(J_{r}\right)_{\text {ave }}=-0.03 \% /{ }^{\circ} \mathrm{C}, H_{c J}$ の温度係数は直線外挿で求め ると, $\alpha\left(H_{c J}\right)=-0.45 \% /{ }^{\circ} \mathrm{C}$ なり， $J_{r}$ の温度係数は $\mathrm{Nd}_{9} \mathrm{Fe}_{76.7} \mathrm{Co}_{8} \mathrm{~W}_{0.3} \mathrm{~B}_{6}$ 組成の温度係数と比べて, 半分の值と いう良好な值であった。

図 13 は最適作製条件で作製された急冷薄帯試料の磁化 $\sigma$ - $T$ 曲線を示したものである。試料は $4.8 \mathrm{MA} / \mathrm{m}$ でパルス着 磁した後, 印加磁界を $160 \mathrm{kA} / \mathrm{m}$ として測定した。図より, $\alpha$ - $\mathrm{Fe}$ 型結晶相と $\mathrm{Pr}_{2} \mathrm{Fe}_{14} \mathrm{~B}$ 型結晶相を含んでいることが分 かり， $\alpha-\mathrm{Fe}$ 型結晶相のキュリー温度は $700{ }^{\circ} \mathrm{C}$ 以上である ことから, $\mathrm{Pr}_{2} \mathrm{Fe}_{14} \mathrm{~B}$ 型結晶相のキュリー温度は $409{ }^{\circ} \mathrm{C}$ であ ることが分かった。またこの図よりそれぞれの結晶相の大 まかな割合は $\alpha-\mathrm{Fe}$ 型結晶相 $40 \%, \mathrm{Pr}_{2} \mathrm{Fe}_{14} \mathrm{~B}$ 型結晶相 $60 \%$ であることが知られた。

図 14 は最適作製条件で作製された急冷薄帯試料を用いて

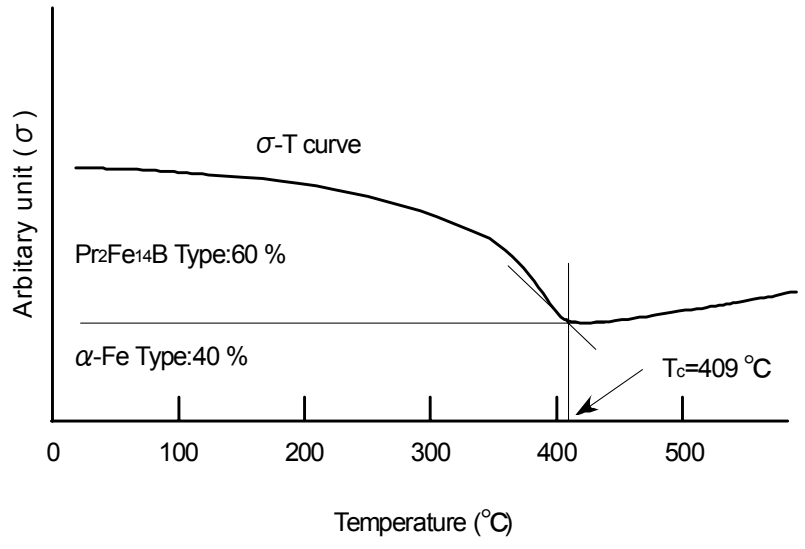

図 $13 \mathrm{Pr}_{9} \mathrm{Fe}$ 76.7 $\mathrm{Co}_{8} \mathrm{~W}_{0.3} \mathrm{~B}_{6}$ 合金急冷薄帯の磁化の 温度依存性

Fig. 13. Temperature dependence of magnetization of melt-spun $\mathrm{Pr}_{9} \mathrm{Fe}_{76.7} \mathrm{Co}_{8} \mathrm{~W}_{0.3} \mathrm{~B}_{6}$ alloy ribbon.

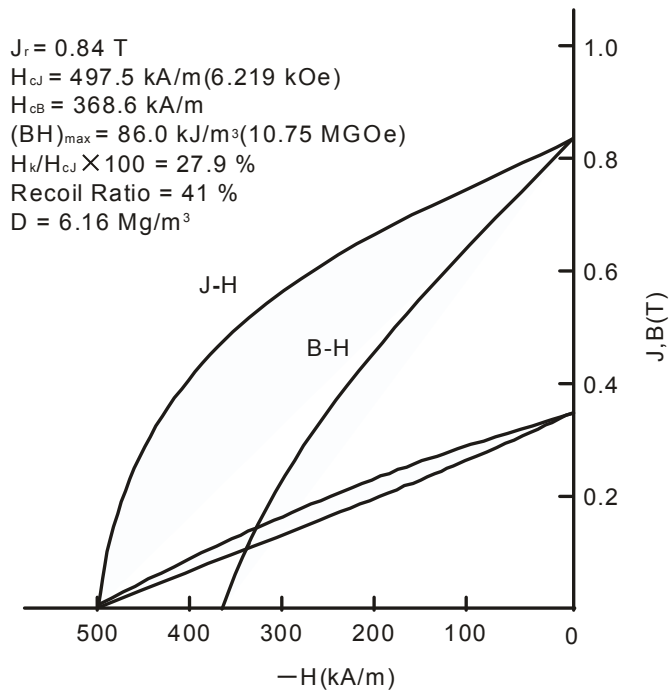

図 $14 \mathrm{Pr}_{9} \mathrm{Fe}_{76.7} \mathrm{Co}_{8} \mathrm{~W}_{0.3} \mathrm{~B}_{6}$ 合金等方性ボンド磁石の 減磁曲線およびスプリングバック

Fig. 14. Demagnetization curves and recoil loop for a bonded magnet prepared by melt-spun $\mathrm{Pr}_{9} \mathrm{Fe}_{76.7} \mathrm{Co}_{8} \mathrm{~W}_{0.3} \mathrm{~B}_{6}$ alloy ribbon.

作製した等方性圧縮成形ボンド磁石の減磁曲線におけるス プリングバックを示したものである。その磁気特性の值は それぞれ $J_{r}=0.84 \mathrm{~T}, H_{c J}=497.5 \mathrm{kA} / \mathrm{m}, H_{c B}=368.6$ $\mathrm{kA} / \mathrm{m}, \quad(B H)_{\max }=86.0 \mathrm{~kJ} / \mathrm{m}^{3}, H_{k} / H_{c J} \times 100=27.9 \%$, Recoil ratio = 41 \%であった。また密度は, $6.16 \mathrm{Mg} / \mathrm{m}^{3}$ であった。

\section{4. 結 言}

以上の結果をまとめると次のようである。

（1）本実験で得られた最適作製条件は, $\mathrm{Pr}_{y} \mathrm{Fe} 92-x y z \mathrm{Co}_{8} \mathrm{~W}_{x} \mathrm{~B}_{z}$ 組成急冷薄帯において $y=9$ at $\%, x=0.3$ at $\%, z=6$ at $\%$ の時であり, ロール周速度 $15.0 \mathrm{~m} / \mathrm{s}$, 熱処理温度 $600{ }^{\circ} \mathrm{C}$, 熱処理昇温時間 $5 \mathrm{~min}$ の時に最高の磁気特性が得られた。 
この時の值は $J_{r}=1.08 \mathrm{~T}, H_{c J}=513.0 \mathrm{kA} / \mathrm{m}, \quad H_{c B}=445.0$ $\mathrm{kA} / \mathrm{m},(B H)_{\text {max }}=148.5 \mathrm{~kJ} / \mathrm{m}^{3}$, 保磁力付近からの Recoil ratio $=42 \%$ であった。

（2）最適条件で作製された薄帯試料の温度係数は， $J_{r}$ の可逆温度係数 $\alpha\left(J_{r}\right)=-0.03 \% /{ }^{\circ} \mathrm{C}, H_{C J}$ の温度係数を直線 外挿より求めると $\alpha\left(H_{c J}\right)=-0.45 \% /{ }^{\circ} \mathrm{C}$ であった。また, 保 磁力付近より磁界を 0 に戻した時, 残留磁化 $J_{r}$ が $42 \%$ 回復 する事が知られ，本組成急冷薄帯は硬質磁性相である $\mathrm{Pr}_{2} \mathrm{Fe}_{14} \mathrm{~B}$ と軟質磁性相である $\alpha-\mathrm{Fe}$ が交換結合している交 換スプリング磁石であることが知られた。また，TEM 観察 の結果より平均粒径は約 $23 \mathrm{~nm}$ であることが分かり，W 添 加により約 $23 \%$ 粒径が小さくなったことが知られた。

（3）最適条件で作製された急冷薄帯試料のキュリー温 度は約 $409{ }^{\circ} \mathrm{C}$ であり, $\mathrm{Pr}_{2} \mathrm{Fe}_{14} \mathrm{~B}$ 型結晶相, $\alpha$ - $\mathrm{Fe}$ 型結晶相 を含んでいることが知られ，それぞれの大まかな割合は $\mathrm{Pr}_{2} \mathrm{Fe}_{14} \mathrm{~B}$ 型結晶相 $60 \% ， \alpha-\mathrm{Fe}$ 型結晶相 $40 \%$ であった。

（4）最適条件で作製された試料を用いて作製したボン ド磁石の磁気特性は $J_{r}=0.84 \mathrm{~T}, H_{c J}=497.5 \mathrm{kA} / \mathrm{m}, H_{c B}=$ $368.6 \mathrm{kA} / \mathrm{m},(B H)_{\max }=86.0 \mathrm{~kJ} / \mathrm{m}^{3}$ であり, この時の密度 は $6.16 \mathrm{Mg} / \mathrm{m}^{3}$ であった。

(平成 14 年 11 月 11 日受付, 平成 15 年 1 月 31 日再受付)

\section{文献}

(1) H. Yamamoto, S. Koumo, and K. Kawamata : "Effect of Pr Substitution on the Magnetic Properties of $\mathrm{Nd}-\mathrm{Fe}^{-} \mathrm{Co}-\mathrm{Cu}-\mathrm{Nb}-\mathrm{B}$ System Exchange Spring Magnets", Proc. of the 16th Int. Workshop on RE Magnets and Their Application, 14, pp.585-590, Sendai, Japan (2000)

(2) H. Yamamoto, M. Nagakura, T. Katsuno, and T. Yamaguchi : "Effect of Annealing Treatment on Magnetic Properties of Melt-Spun Nd-Fe-Co-B-V Ribbons", J.Magn.Soc.Jpn., Vol.14, No.2, pp.185-188 (1990) (in Japanese)

山元 洋・永倉 充・勝野 徹・山口岳人: 「 $\mathrm{Nd}-\mathrm{Fe}-\mathrm{Co}-\mathrm{B}-\mathrm{V}$ 系急冷 薄带の磁気特性に及ぼす熱処理の影響」, 応用磁気学誌, 14, No.2, pp.185-188 (1990)

(3) H. Yamamoto, K. Kawamata, M. Hamano, and M. Yamasaki : "Magnetic Properties of $\mathrm{Nd}-\mathrm{Fe}-\mathrm{Co}-\mathrm{V}-\mathrm{Nb}-\mathrm{B}$ System Exchange Spring Magnets", J.Magn.Soc.Jpn., Vol.24, No.4-2, pp.415-418 (2000) (in Japanese)

山元 洋・川又健二・浜野正昭・山崎 実: 「 $\mathrm{Nd}-\mathrm{Fe}-\mathrm{Co}-\mathrm{V}-\mathrm{Nb}-\mathrm{B}$ 系 交換スプリング磁石の磁気特性」, 応用磁気学誌, 24, No.4-2, pp.415-418 (2000)

(4) Z. Chen, Y. Zhang, Y. Ding, G. C.Hadjipanayis, Q. Chen, and B. $\mathrm{Ma}$ : "Studies on magnetic properties and microstructure of melt-spun nanocomposite $\mathrm{R}_{8}(\mathrm{Fe}, \mathrm{Co}, \mathrm{Nb})_{86} \mathrm{~B}_{6}(\mathrm{R}=\mathrm{Nd}$, $\mathrm{Pr})$ magnets", J.Magn.Mat, Vol.195, pp.420-425 (1999)
(5) H. Yamamoto and Y. Tsukada : "Magnetic Properties of $\mathrm{TbCu}_{7}$-Type $\mathrm{Sm}-\mathrm{Fe}^{-} \mathrm{Co}-\mathrm{W}$ System Nitriding Compounds", JSPM, Vol.49, pp.151-156 (2002) (in Japanese)

山元 洋・塚田祐二郎：「 $\mathrm{TbCu}_{7}$ 型 $\mathrm{Sm}-\mathrm{Fe}-\mathrm{Co}-\mathrm{W}$ 系窒化化合物磁石 の磁気特性」，粉体および粉末治金誌，49, pp.151-156 (2002)

(6) D. Goll and H. Kronmüller : "Nanocrystalline PrFeB -Based Permanent Magnets with enhanced remanence", Proc. of the 15th Int. Workshop on RE Magnets and Their Application, pp.189-194, Dresden, Germany (1998)

(7) H. A. Davies, J. I. Betancourt R., and C. L. Harland : "Nanophase Pr and Nd/Pr-Based Rare Earth -Iron-Boron Alloys." Proc. of the 16th Int. Workshop on RE Magnets and Their Application, 14, pp.485-490, Sendai, Japan (2000)

(8) D. Goll, I. Kleinschroth, and H. Kronmüller : "High Performance Nanocrystalline PrFeB-Based Bonded Magnets", Proc. of the 16th Int. Workshop on RE Magnets and Their Application, 14, pp.641-646, Sendai, Japan (2000)

(9) S. Hirosawa, H. Kanekiyo, and M. Uehara : "High coercivity iron-rich rare-earth permanent magnet material based on $(\mathrm{Fe}$, Co $)_{3} \mathrm{~B}-\mathrm{Nd}-\mathrm{M}(\mathrm{M}=\mathrm{Al}, \mathrm{Si}, \mathrm{Cu}, \mathrm{Ga}, \mathrm{Ag}, \mathrm{Au}) "$, J.Appl.Phys., Vol.73, pp.6448-6553 (1993)

(10) H. Yamamoto and M. Shiozawa : "Magnetic Proper -ties of Melt-spun Nd-Fe-Co-V-B System Exchange Spring Magnets and their Bonded Magnets", Proc. of $10^{\text {th }}$ Int. Workshop on RE Magnets and Their Application, pp.307-312, Dreaden, Germany (1998)

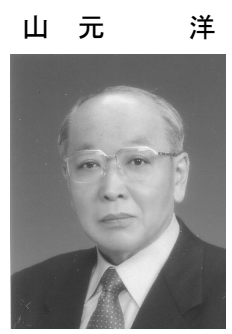

（正員） 1941 年 3 月 23 日生まれ。1969 年 3 月明治大学院工学研究科博士課程終了。以後, 同大学工学部電気工学科 (改組により, 現在は 理工学部電気電子工学科) 助手, 講師, 助教授 を経て, 81 年 4 月同教授, 現在に至る。工学 博士。この間, 84 年 3 月〜 $~ 9$ 月アイオワ州立大 学電気工学科客員教授。主として, 磁性材料に 関寸る研究に従事。95 年粉体粉末治金協会研究 研究功績賞受賞。96 年電気学会技術報告賞受賞。IEEE, 日本応用 磁気学会, 日本金属学会, 粉体粉末治金協会会員。

木 正 親

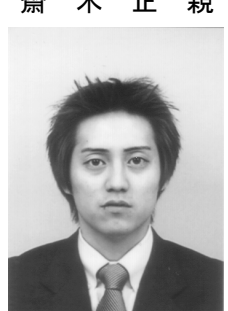

(学正員) 1978 年 10 月 14 日生まれ。 2001 年 3 月明治大学理工学部電気電子工学科卒業。 同年 4 月同大学理工学研究科電気工学専攻博士 前期課程入学，現在に至る。 